\title{
Distribution Characteristics of TOC, TN and TP in the Wetland Sediments of Longbao Lake in the San-Jiang Head Waters
}

\author{
Sujin $\mathrm{LU}^{1}$, Jianhua $\mathrm{SI}^{2}$, Yue $\mathrm{QI}^{1}$, Zhanqing $\mathrm{WANG}^{1}$, Xiaocui $\mathrm{WU}^{1}$, \\ and Chuanying $\mathrm{HOU}^{1}$ \\ ${ }^{1}$ Eco-environmental Engineering College, Qinghai University, Xi'ning, \\ Qinghai Province, China; e-mail: lusujin88@163.com (corresponding author) \\ ${ }^{2}$ College of Agriculture and Animal Husbandry, Qinghai University, \\ Xi’ning, Qinghai Province, China
}

\begin{abstract}
The study deals with the distribution of nutrients in wetland sediments, which provide the basis for revealing the wetland eutrophication processes and mechanisms of internal pollution sources. The total organic carbon (TOC), total nitrogen (TN), and total phosphorus (TP) contents and distribution characteristics of sediment samples were examined. The results showed that the TOC concentration ranged from 3.81 to $15.6 \mathrm{~g} / \mathrm{kg}$, the TN concentration ranged from 0.21 to $1.18 \mathrm{~g} / \mathrm{kg}$ with a mean concentration of $0.66 \mathrm{~g} / \mathrm{kg}$, and the TP concentration ranged from 0.16 to $0.35 \mathrm{~g} / \mathrm{kg}$ with a mean of $0.23 \mathrm{~g} / \mathrm{kg}$. Statistical analysis showed close correlations between TOC and TN $\left(R^{2}=0.96\right)$, and TN and TP $\left(R^{2}=0.97\right)$, which indicated that the TN and TP in the sediments were from similar sources. The concentrations of TOC, TN, and TP in Longbao Lake wetland sediments were too low for eutrophication to occur. Our investigation indicated that Longbao Lake undergoes natural evolution rather than anthropogenic activities.
\end{abstract}

Key words: Longbao Lake, sediments, organic carbon, nitrogen, phosphorus, high altitude wetlands. 


\section{INTRODUCTION}

Wetlands are referred to as "the kidneys of the Earth", with the richest biodiversity, important for mankind. Wetlands play important roles in climate regulation, water conservation, protection of biological diversity and provision of resources for human production and life (Barbier et al. 1997; Mitch and Gosselink 2000). Alpine wetlands are important wetland types, which are generally distributed in cold zones with high altitudes (Sun and Liu 2006). The important distribution area for alpine wetlands in China are Qinghai Tibetan Plateau, covering $13300000 \mathrm{~km}^{2}$, with an average elevation of more than $3000 \mathrm{~m}$. The San-Jiang-Yuan Nature Reserve in the Qinghai Tibetan Plateau is located in the headwaters of the Yangtze, Yellow and Lancang Rivers, considered as a source for rivers and Chinese water towers, where rivers are densely developed and numerous lakes, swamps, snowcovered mountains and glaciers are widely distributed (Ma et al. 2009). Wetland ecosystems with the San-Jiang-Yuan Nature Reserve, including alpine swamps, alpine swampy meadows and alpine lakes, play crucial roles in water storage, recharging for surrounding areas and moderation of local and global climate (Lin 2008). Thus, the San-Jiang-Yuan Nature Reserve is of significant interest for ecological safety in China and around the world.

However, the simple structure of cold wetland ecosystems manifests itself in a relatively uniform composition, a weak system regulation ability as well as low ecological capacity and resilience. Therefore, cold wetland ecosystems are particularly sensitive to climate and environmental changes that cause wetland degradation in San Jiang Yuan Nature Reserve (Yang et al. 2008). The areas of forest and grasslands in the area of Longbao Lake in San-Jiang-Yuan Nature Reserve have been decreasing, and the permanent area of snow glaciers is currently only $24276.6 \mathrm{hm}^{2}$, which represents a reduction of $85 \%$. The lake and swamp area, as a representative area for wetlands, was shrinking, and the area of swamp decreased by $0.93 \% \mathrm{a}^{-1}$ $\left(487.3 \mathrm{hm}^{2} \mathrm{a}^{-1}\right)$ (Zheng 2011). Considering recent global warming and environmental damage and pollution, the ecological systems and water resources in the wetlands in San Jiang Yuan are seriously threatened. Furthermore, the water quality is a great concern for the wetland. The excess of nutrients into lakes can result in the destruction of the lake's ecosystem and water quality deterioration (Li et al. 2001). P and N pollutants are released from sediments and can enter the water over a long period, which results in a significant amount of $\mathrm{P}$ in the water column (Ding et al. 2015). High internal P loading is frequently reported as a major factor that is responsible for delaying lake recovery after reducing external P loading (Ding et al. 2015, Søndergaard et al. 2007). Nutrient salt in sediments is co-related to exogenous pollution in wetland ecosystems. Although many researchers have recently conducted 
extensive studies of nitrogen and phosphorus sediments in lake ecosystems, most of these studies have focused on the release of nitrogen and phosphorus from sediments. The release of nitrogen and phosphorus from sediments contributes to exogenous pollution and water quality deterioration, which impact the organic matter in the sediments and the synergistic reactions with other biogenic elements in the lake. However, studies regarding the biogenic elements and environmental elements of lakes are lacking.

Currently, studies of the San Jiang Yuan headwaters mainly involve soil water heat processes, the deterioration of alpine wetlands, the effects of grazing on grassland reserves, and the responses of wetlands to regional climate changes (Lin 2003, Ma et al. 2009, Chen et al. 2012). However, studies on the distribution characteristics and potential variation tendencies of nutrient salts in sediments, with alpine lakes in the San-Jiang head source, have not been reported ( $\mathrm{Lu}$ et al. 2009). Research regarding the TOC, TP, and TN contents with sediment quality in alpine lakes is necessary to understand the eutrophication potential in such lakes, and protect alpine wetland, which are important for maintaining a healthy, reasonable, sustainable and ecological environment in the plateau. The objectives of this study were to measure the TOC, TN, and TP contents and their distribution characteristics in sediments in Longbao Lake to reveal changes in nutrient ( $\mathrm{N}$ and $\mathrm{P}$ ) contents, determine the mechanisms of endogenous pollution in the Longbao Lake wetland, and provide a scientific basis for preventing eutrophication in Longbao Lake wetlands and references for damaged wetland restoration.

\section{MATERIALS AND METHODS}

\subsection{Study site description}

Longbao Lake covers an area of approximately $50 \mathrm{~km}^{2}(18.7 \mathrm{~km} \times 3 \mathrm{~km})$ and is located in the Longbao Nature Reserve in the Yushu Tibetan Autonomous Prefecture of Yushu county in Qinghai Province $\left(\mathrm{N} 33^{\circ} 09^{\prime} \sim 33^{\circ} 16^{\prime}\right.$, $\mathrm{E}^{\circ} 96^{\circ} 24^{\prime} \sim 96^{\circ} 37^{\prime}$ ) (Fig. 1). The Longbao Lake Nature Reserve is located on an average altitude of $4500 \mathrm{~m}$ covering a total area of $147.2 \mathrm{~km}^{2}$. The reserve is located from the center to the surrounding regions, followed by lakes, swamps, marshes, meadows, alpine meadows, alpine mountain meadows, and bare rock lands. Thus, this region is considered to have a typical plateau continental climate (Lin 2003). Rainfall is concentrated from June to August, and approximately $2300 \mathrm{~h}$ of sunshine occur throughout the year. The annual precipitation in this region is $730 \mathrm{~mm}$. The lake freezes in November and the ice is melted over the next May.

There are 33 types of birds in the Longbao nature reserve, including black-necked crane (Grus nigricollis) (Shi et al. 2009). The ecosystem involves lakes, marshes, swamp meadow, with Charophytes (Chara fragilis 


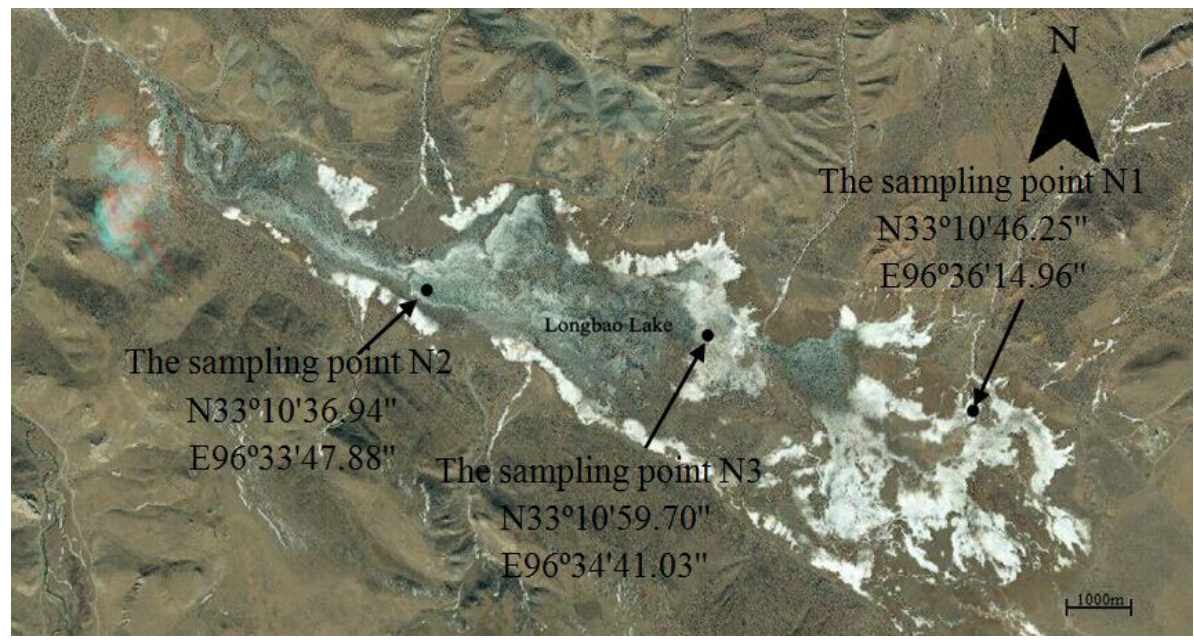

Fig. 1. Study area location and sampling station distribution.

Desv), Cedrus folium algae (Hippuris vulgaris L), etc., which are the main aquatic plants. The dominant plants in the Longbao Lake Nature Reserve are Aqua Buttercup (Batrachium bungei (Steud.) L. Liou), Siberia Polygonum (Polygonum sibiricum Laxm), Humilis (Kobresia myosuroides Fiori), Dwarf Nasturtium (Trollius farreri Stapf), and Water Winter Wheat (Triglochin palustre). The total population of the Long Lake Nature Reserve is 370000 , and animal husbandry is the main economic pillar in the region (Qing 2013). Currently, the entire periphery of the wetland is surrounded by chain link fence and human grazing is not permitted, with the purpose of reducing pollution and destruction of the wetland by human and grazing.

The upstream of Longbao Lake is the largest inflow river Yiqu, with flow of $21 \mathrm{~m}^{3} / \mathrm{s}$, annual runoff of $6.61 \times 10^{9} \mathrm{~m}^{3}$. Yiqu river, Dengeyongqu river and Kequ river are large flowing rivers, with flow of 20.5, 20.8, and $20.9 \mathrm{~m}^{3} / \mathrm{s}$, respectively, while the annual runoff was $5.34 \times 10^{9}, 5.27 \times 10^{9}$, and $5.47 \times 10^{9} \mathrm{~m}^{3}$. The water temperature was $13.4{ }^{\circ} \mathrm{C}$, $\mathrm{pH}$ was 7.9 , conductivity was $0.66 \mathrm{~ms} / \mathrm{cm}$, DO was $7.43 \mathrm{mg} / \mathrm{L}, \mathrm{BOD}_{5}$ was $2.92 \mathrm{mg} / \mathrm{L}$, and COD was $14.68 \mathrm{mg} / \mathrm{L}$ in Yiqu river. In Dengeyongqu river, the water temperature was $13.6{ }^{\circ} \mathrm{C}$, pH was 8.0 , conductivity was $0.69 \mathrm{~ms} / \mathrm{cm}$, DO was $7.64 \mathrm{mg} / \mathrm{L}$, $\mathrm{BOD}_{5}$ was $2.96 \mathrm{mg} / \mathrm{L}$, and COD was $14.99 \mathrm{mg} / \mathrm{L}$. In Kequ river, the water temperature was $13.2^{\circ} \mathrm{C}$, $\mathrm{pH}$ was 7.8 , conductivity was $0.63 \mathrm{~ms} / \mathrm{cm}$, DO was $7.22 \mathrm{mg} / \mathrm{L}, \mathrm{BOD}_{5}$ was $2.94 \mathrm{mg} / \mathrm{L}$, and COD was $15.11 \mathrm{mg} / \mathrm{L}$.

The Longbao town, the road and wetland animals are the major sources of pollution surrounding the Longbao Lake. Longbao town is situated west of Longbao Lake, $17 \mathrm{~km}$ from the lake, with a population of 8623 . Untreated 
sewage from residents of Longbao town will input into the lake by runoff, causing water pollution. The road is about $500 \mathrm{~m}$ away, to the north of the lake. So, grazing animals, vehicles and tourists passing by could result in automobile exhaust, dust, manure, garbage, which may pollute the lakes.

\subsection{Basin shape}

The lake is supplied by waters from surrounding mountains. Recent years, the permanent glaciers around the Longbao Lake area decreased with global climate changing, the area of wetland and swamp presents a declining trend, the water exchange cycle of Longbao Lake extended, the water input to the Longbao Lake decreased, and the self cleaning capacity weakened.

\subsection{Experimental design and sampling}

In order to avoid interference of water level, which is too high in the Lake for sampling, samples were collected during the dry season. To compare the related data from each sampling point and to consider the integrity of the watershed layout, three representative locations were selected (N1, N2, and N3) and stratified sediment samples were collected at sites N1, N2, and N3 (Fig. 1). Sampling was conducted in October 2012, May 2013, October 2013, May 2014, and October 2014. Each sampling site was located using a global satellite navigation and positioning system for precise positioning. For sampling, an open type stainless steel cylindrical sediment sampler was used.

Longbao Lake sediment profile sample hierarchy is as follows: three points were taken from the $50 \mathrm{~cm}$ mud column; use the mud collector to collect the overlying water; try to reduce the disturbance of surface sediments. Each $5 \mathrm{~cm}$ mud column was considered as one sample of the profile. All the samples were taken back to the lab and dried by indoor natural air, and different levels of sediment were sieved according to the corresponding determination and analysis methods (Guo 2007).

Before analyzing total $\mathrm{N}$, total $\mathrm{P}$, and TOC contents, the sediments were air-dried and passed through a 1 and $0.25 \mathrm{~mm}$ sieve and were stored in cloth bags to keep out the light. The total P content was determined by colorimetry using the phospho-molybdate reduction method, which is briefly described in the publication quoted as: ISSCAS (1987). Firstly, weigh $0.5 \mathrm{~g}$ sediment sample, and put it in a triangular flask. Add $6 \mathrm{~mL}$ concentrated sulfuric acid and 10 drops of perchlorate. Put it on the electric furnace to be digested until a colorless. The sediment sample was decomposed. Then a standard curve was drawn. Then, the sediment samples were placed into a colorimetric tube. Add digested sediment samples and 2 3 drops of 2-, 4-nitro phenol indicator. Adjust the pH. Next, the $1 \mathrm{ml} 10 \%$ ascorbic acid and $2 \mathrm{ml} 0.22 \mathrm{~mol} / \mathrm{L}$ 
molybdate solutions were added and the tubes were shaken for $15 \mathrm{~min}$. The absorbance at $700 \mathrm{~nm}$ was measured using a Spectrophotometer (manufactured by Agilent Technologies Inc.). The total $\mathrm{N}$ content was measured on soil samples that were digested in $98 \% \mathrm{H}_{2} \mathrm{SO}_{4}$ by using the modified semimicro-Kjeldahl procedure. The potassium bichromate-concentrated sulfuric acid oxidation process was used to measure the TOC content which is briefly described here. First, 0.25 0.40 g of the prepared samples (weighting error of to $0.0001 \mathrm{~g}$ ) was mixed with $10 \mathrm{ml}$ of a $4 \mathrm{~mol} / \mathrm{L}$ potassium dichromate-sulfuric acid standard solution and heated to $200 \sim 230{ }^{\circ} \mathrm{C}$ for $5 \pm 0.5 \mathrm{~min}$. At the treatment, add $10 \mathrm{ml} 4 \mathrm{~mol} / \mathrm{L}$ the standard potassium dichromate into concentrated sulfuric acid medium. Under heating at $200 \sim 230{ }^{\circ} \mathrm{C}$ conditions for $5 \pm 0.5 \mathrm{~min}$, the organic carbon in the sample is oxidized to carbon dioxide. That's it. Organic carbon sedimented on the bottom of the flask was oxidized and the concentration of potassium dichromate remaining in the supernatant was measured by titration with a $0.2 \mathrm{~mol} / \mathrm{L}$ ferrous sulfate standard solution. The TOC content was calculated from the amount of consumed oxidant (ISSCAS 1987).

\subsection{Statistical analysis}

We used the Excel statistical software package version 2007 to sort data. The vertical trend charts of TOC, TN, and TP were made using the Origin Software Package Version 8.1. In this paper, the regression approach was used to the analysis of variance (ANOVA) in the SPSS software package version 17.0.

\section{RESULTS}

\subsection{The spatial characteristics of the TOC, TP, and TN contents in the sediments}

The TOC, TP, and TN concentrations varied in the three sampling sites from the Longbao Lake wetlands. With $0-50 \mathrm{~cm}$ sediments in Longbao Lake, the TOC, TP, and TN content were 3.81-15.6 g/ $/ \mathrm{kg}$ (averaging $8.502 \mathrm{~g} / \mathrm{kg}$ ), 0.21 $1.18 \mathrm{~g} / \mathrm{kg}$ (averaging $0.614 \mathrm{~g} / \mathrm{kg}$ ), and $0.16-0.35 \mathrm{~g} / \mathrm{kg}$ (averaging $0.216 \mathrm{~g} / \mathrm{kg}$ ), respectively (Fig. 2). In the three sampling sites, the TOC, TP, and TN content of N2 were higher than those of N1, and the N3 were the lowest (Fig. 2). The average TOC concentrations of N1, N2, and N3 were 10.062, 9.715, and $5.728 \mathrm{~g} / \mathrm{kg}$, respectively, while for TP were $0.795,0.69$, and $0.357 \mathrm{~g} / \mathrm{kg}$, respectively, and for TN they were $0.238,0.222$, and $0.190 \mathrm{~g} / \mathrm{kg}$, respectively (Fig. 2).

The TOC, TP, and TN in N1, N2, and N3 reduced gradually with the increase of sediment depth (Figs. 2-4). In the three sampling sites, the concentrations of TOC, TP, and TN in October were slightly higher than that in 


\section{TOC}

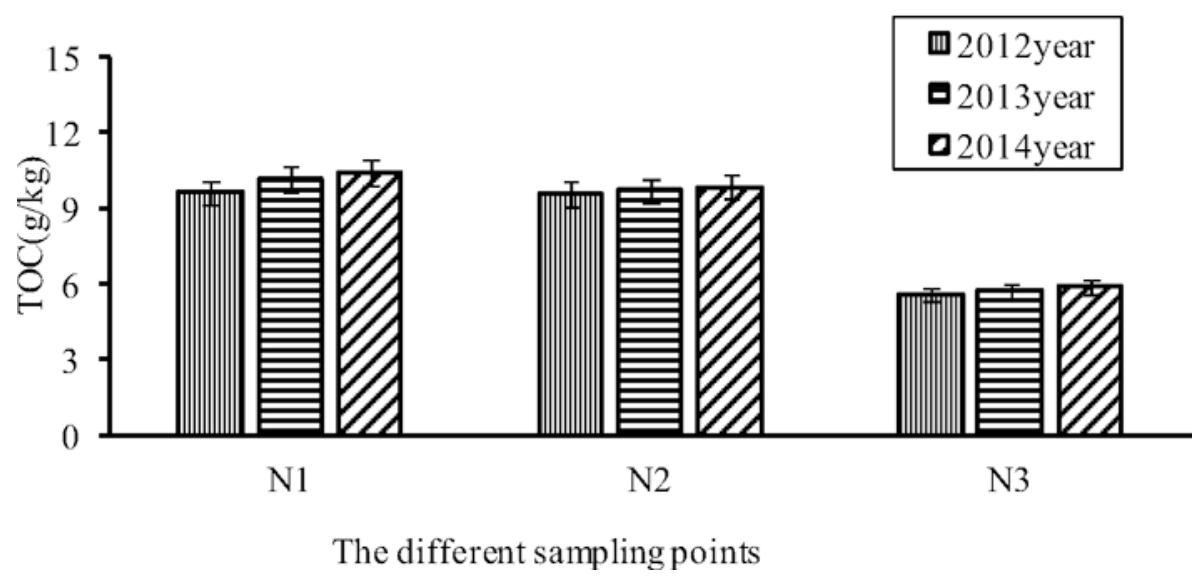

Fig. 2. Interannual variability of TOC content in sediments of different sampling sites.

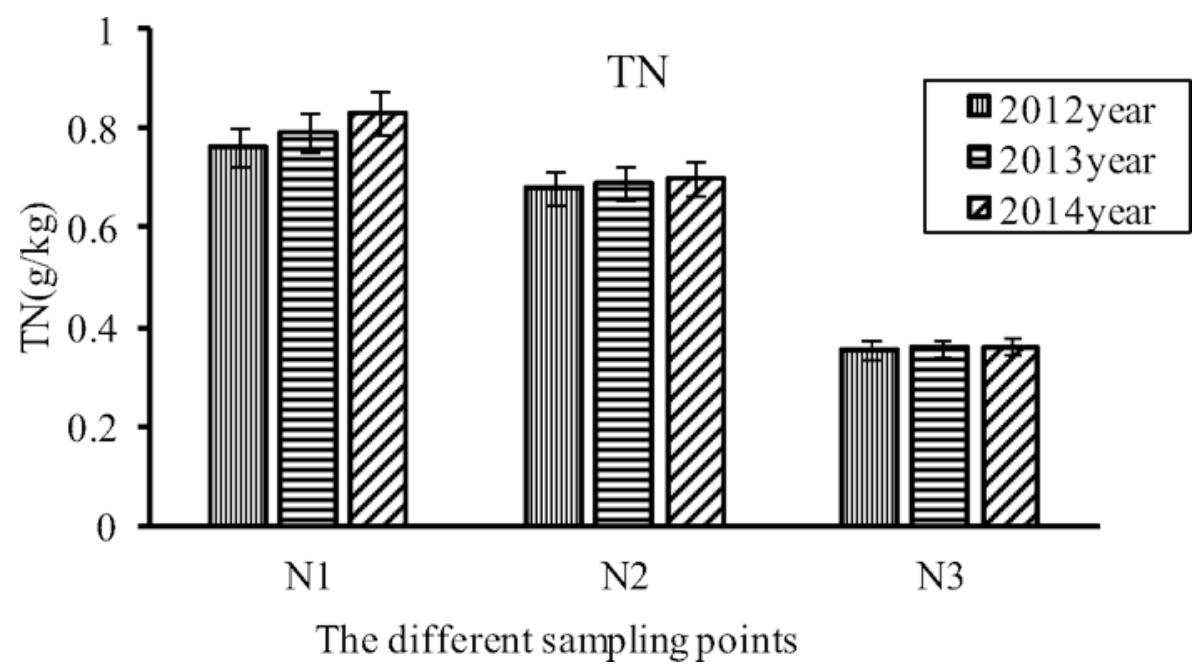

Fig. 3. Interannual variability of TN content in sediments of different sampling sites.

May (Figs. 2-4). In the three sampling sites, no significant difference was detected for TOC, TN, and TP, from 2011 to 2013. However, the average values on TOC, TN, and TP were in a continuous increasing tendency. In the three sampling sites, the TOC, TN, and TP in 2013 were increased by $3-8$, $2-9$, and 8-10\%, respectively, compared to these in 2011 (Figs. 5-7). 


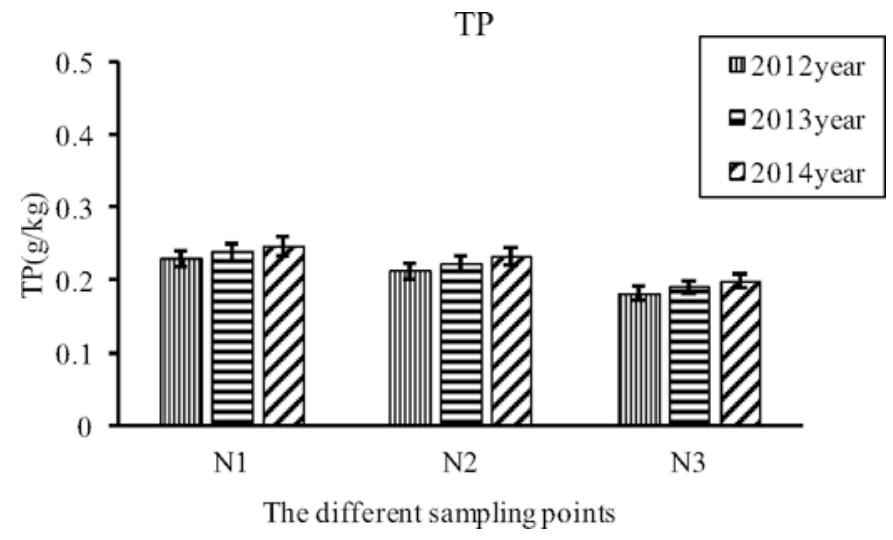

Fig. 4. Interannual variability of TP content in sediments of different sampling sites.

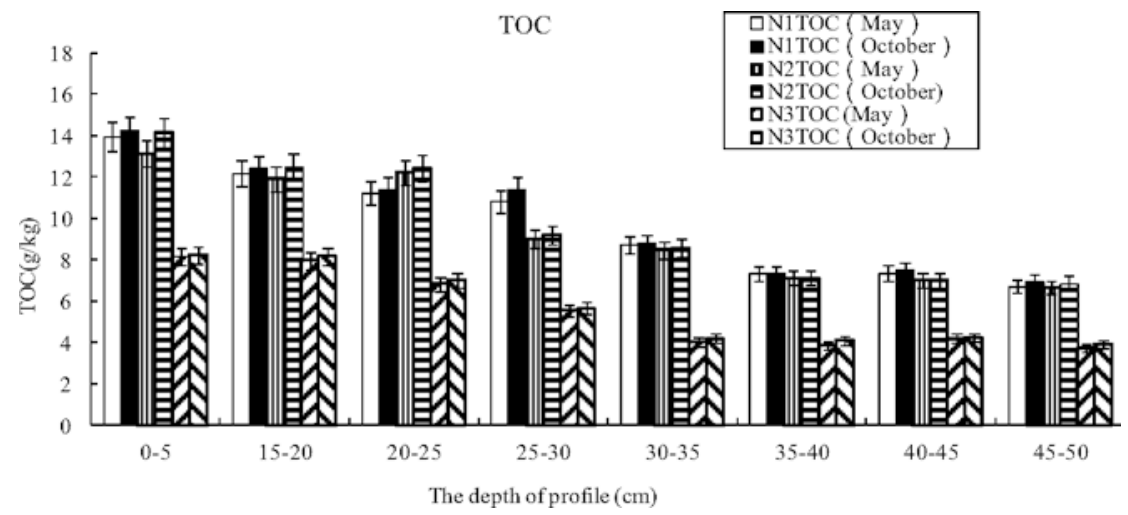

Fig. 5.Comparison of TOC content in October and May at different sediment depths of N1, N2, N3 sampling points.

TP

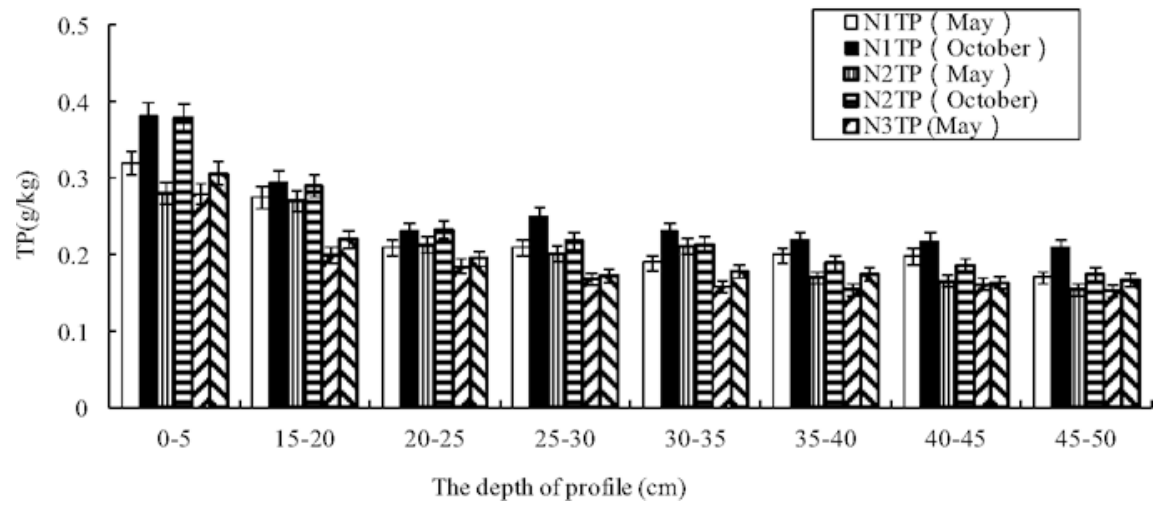

Fig. 6. Comparison of TP content in October and May at different sediment depths of N1, N2, N3 sampling points. 


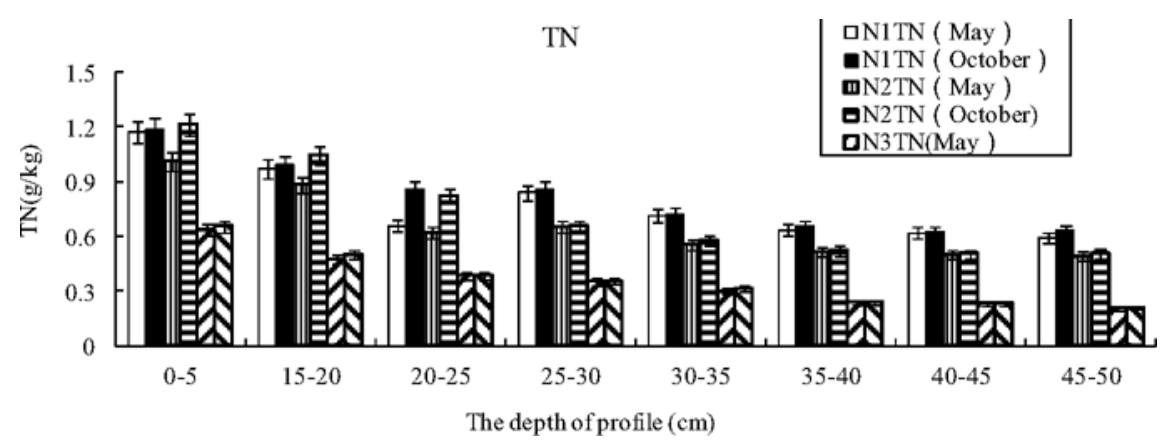

Fig. 7. Comparison of TN content in October and May at different sediment depths of N1, N2, N3 sampling points.

\subsection{Correlation of TOC and TN, TN and TP}

The TOC and TN contents varied from $3.81-15.6 \mathrm{~g} \mathrm{~kg}^{-1}$ to $0.21-1.18 \mathrm{~g} \mathrm{~kg}^{-1}$, respectively (Figs. 8-11). Although the TOC and TN concentrations varied with soil depth, a strong correlation was observed between the TOC and TN concentrations $\left(r^{2}=0.960\right)$. The TOC/TN ratio in the sediment, as an effective indicator of the source of organic matter ( $\mathrm{Li}$ and Song 2005), varied from 11.14 to 18.14 in Longbao Lake, with an average of 14.31 (Fig. 12).

The TN and TP concentrations followed nearly the same trends through the soil profile (Figs. 9-11). The TN was positively correlated with TP in the soil profile $\left(\mathrm{R}^{2}=0.968\right)$, which indicated a strong correlation between the two nutrients in the wetland sediments of Longbao Lake. The TN/P ratios in the sediments from Longbao Lake varied from 1.31 to 3.76, with an average of 2.79 (Fig. 13). Thus, the same source contributed to the $\mathrm{N}$ and $\mathrm{P}$ pollution in Longbao Lake. The TN and TP concentrations were relatively higher in the surface sediments, which indicated that the Longbao Lake Wetland was surrounded by meadows, increasing TN and TP to the lake.

\section{DISCUSSION}

\subsection{The TOC, TP, and TN contents in the sediments}

The water quality with alpine lake is a great concern for protecting the ecosystem in San Jiang Yuan, which is the head water source of the Yangtze and Yellow Rivers. The documents revealed that with the water physical and chemical indexes in San Jiang Yuan, the wetlands had a great water quality with the type I standard for (GB3838-2002 standards for surface water environment quality) (Lu et al. 2009, Shi et al. 2009). In our study, with low nutrients inputs in $0-50 \mathrm{~cm}$ sediments (the $8.502 \mathrm{~g} / \mathrm{kg} \mathrm{TOC}, 0.614 \mathrm{~g} / \mathrm{kg}$ TP, $0.216 \mathrm{~g} / \mathrm{kg} \mathrm{TN})$, the water in the Longbao Lake had a good quality without eutrophication. Some research reported $12.9 \mathrm{ueq} / \mathrm{L}$ TN and $5.6 \mathrm{ug} / \mathrm{L}$ TP in sediment in European alpine lakes without eutrophication (Catalan et al. 
(a)

(b)

$\mathrm{TOC}(\mathrm{g} / \mathrm{kg})$

$\mathrm{TOC}(\mathrm{g} / \mathrm{kg})$
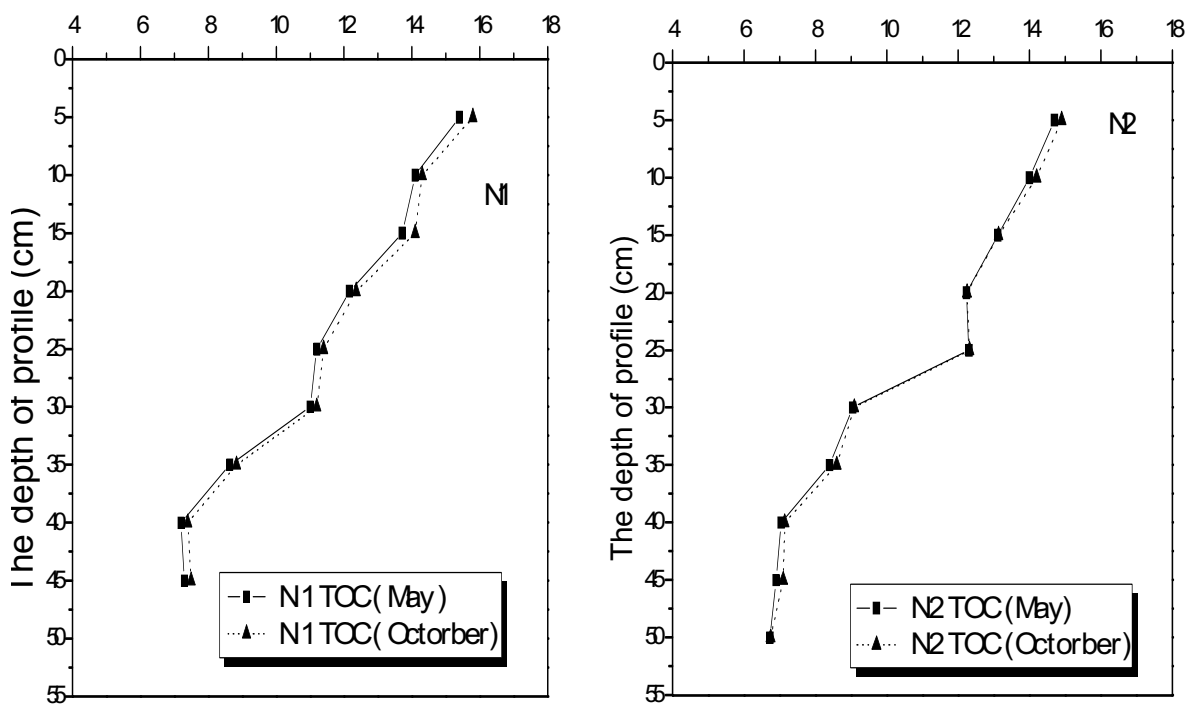

(c)

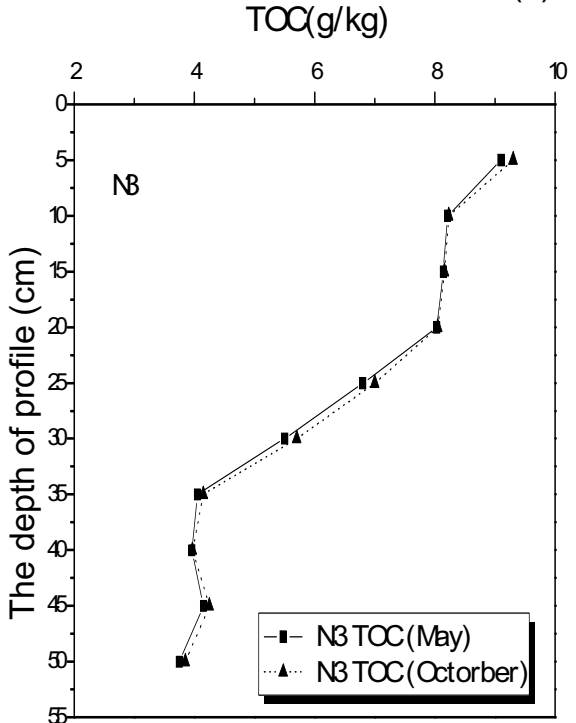

Fig. 8. The chart of profile distribution of TOC in the sampling points $\mathrm{N} 1(\mathrm{a})$, $\mathrm{N} 2$ (b), and N3 (c).

2009). However, eutrophication still should be a great concern for the Longbao Lake, based on $\mathrm{N}$ and $\mathrm{P}$ inputs in the sediment. In the three sampling years, from 2011 to 2013, the interannual significant difference was not observed (Figs. 5-7), but the slightly continuous increases on TOC, TN, and TP with the sediments suggested that more and more nutrients could be input 
$\mathrm{TN}, \mathrm{TP}(\mathrm{g} / \mathrm{kg})$

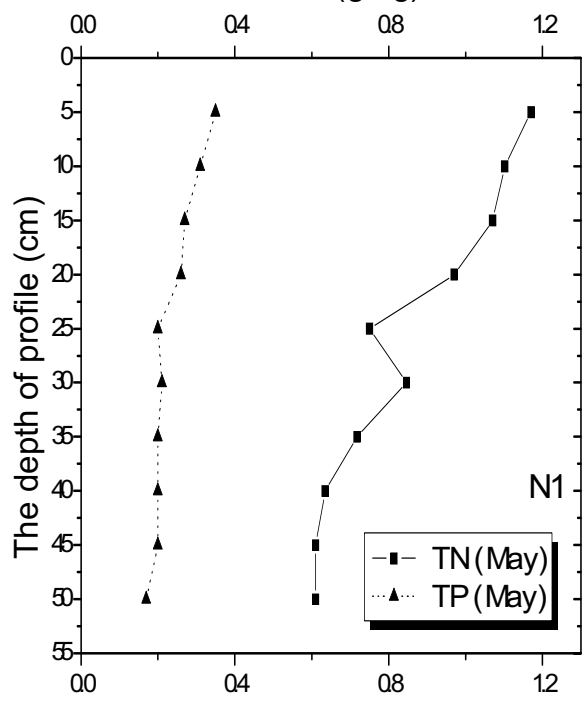

$\mathrm{TN}, \mathrm{TP}(\mathrm{g} / \mathrm{kg})$

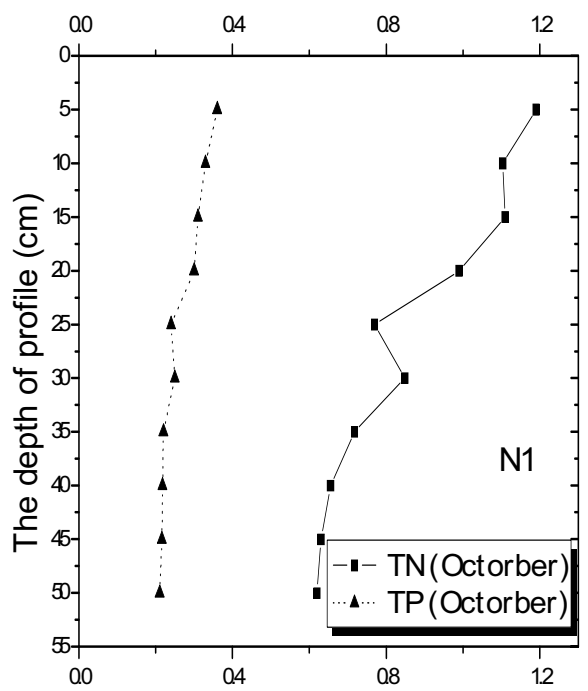

Fig. 9. The chart of profile distribution of TN and TP in the sampling points N1.

$\mathrm{TN}, \mathrm{TP}(\mathrm{g} / \mathrm{kg})$

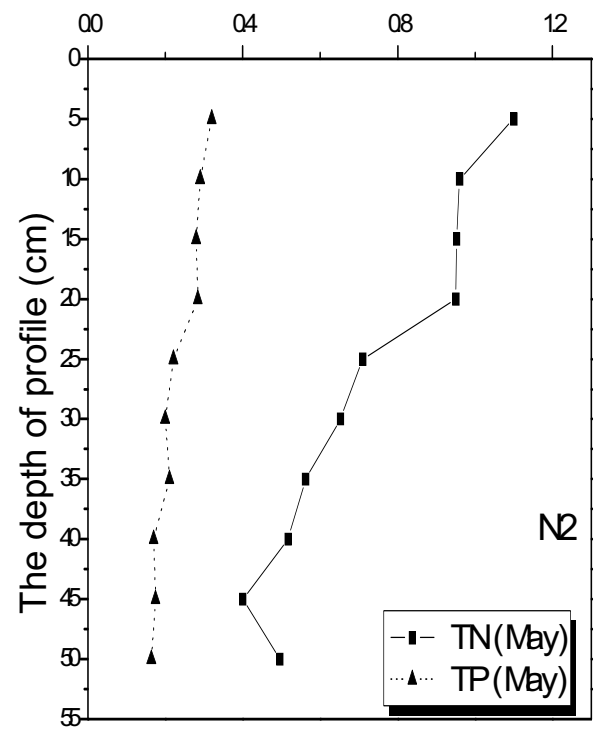

$\mathrm{TN}, \mathrm{TP}(\mathrm{g} / \mathrm{kg})$

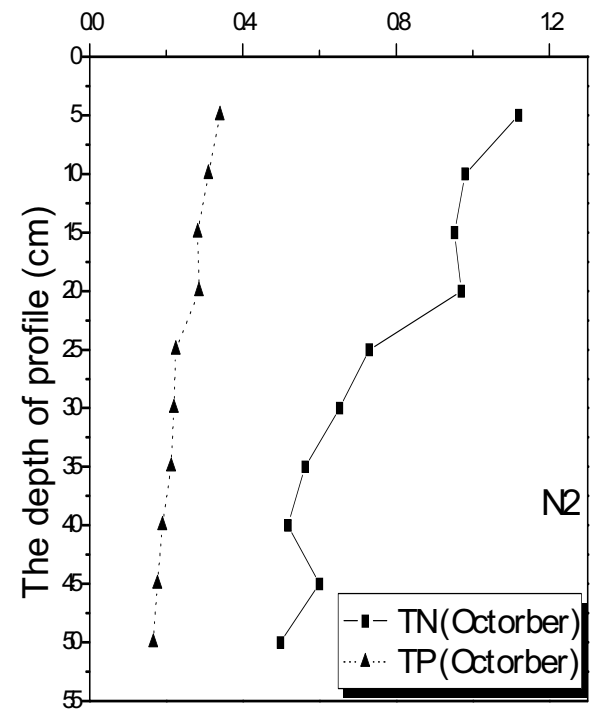

Fig. 10. The chart of profile distribution of TN and TP in the sampling points N2. 
$\mathrm{TN}, \mathrm{TP}(\mathrm{g} / \mathrm{kg})$

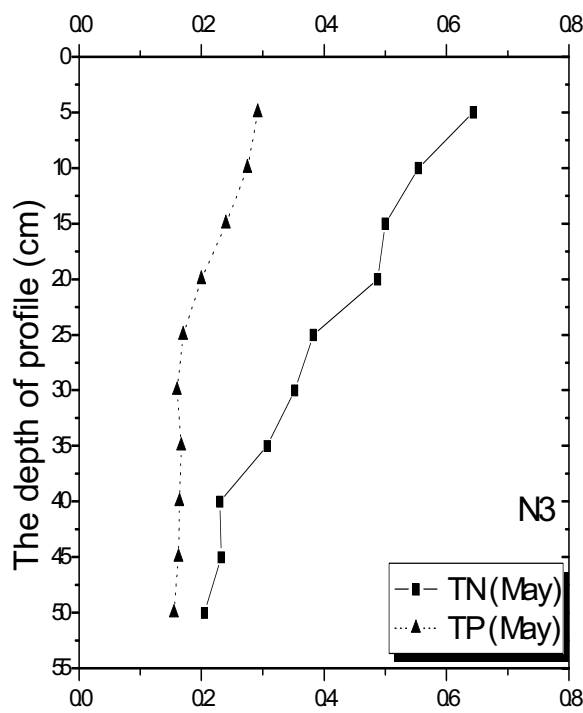

$\mathrm{TN}, \mathrm{TP}(\mathrm{g} / \mathrm{kg})$

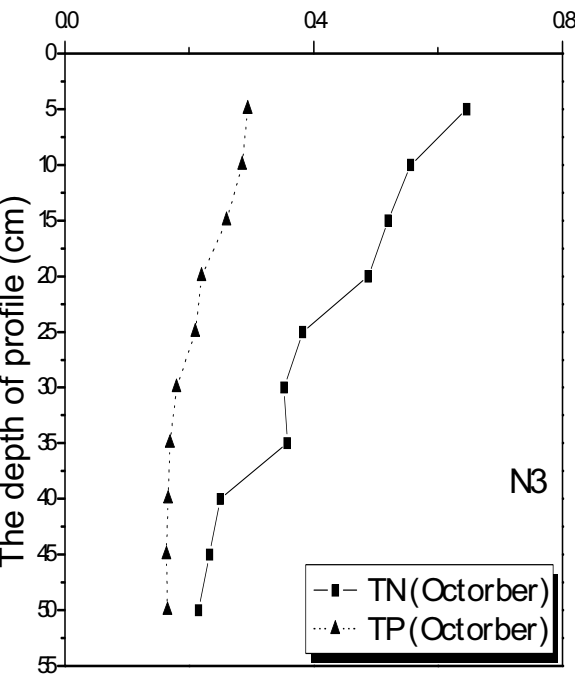

Fig. 11. The chart of profile distribution of TN and TP in the sampling points N3.

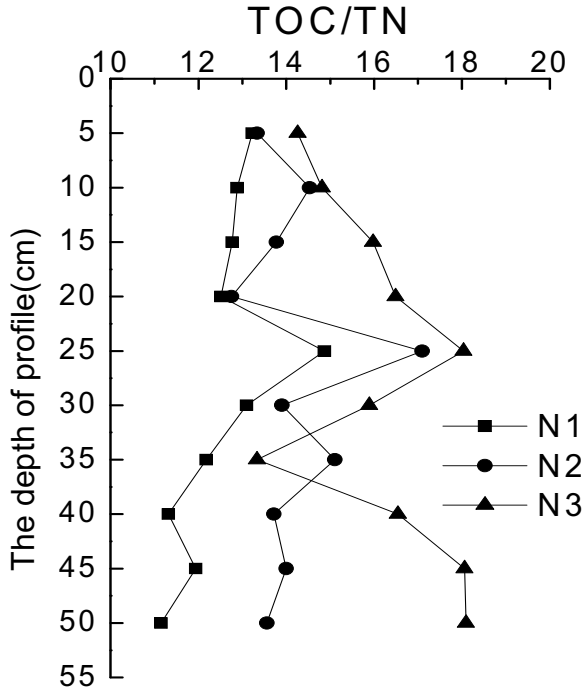

Fig. 12. The vertical distribution of TOC/TN of each sampling point.
$\mathrm{TN} / \mathrm{TP}$

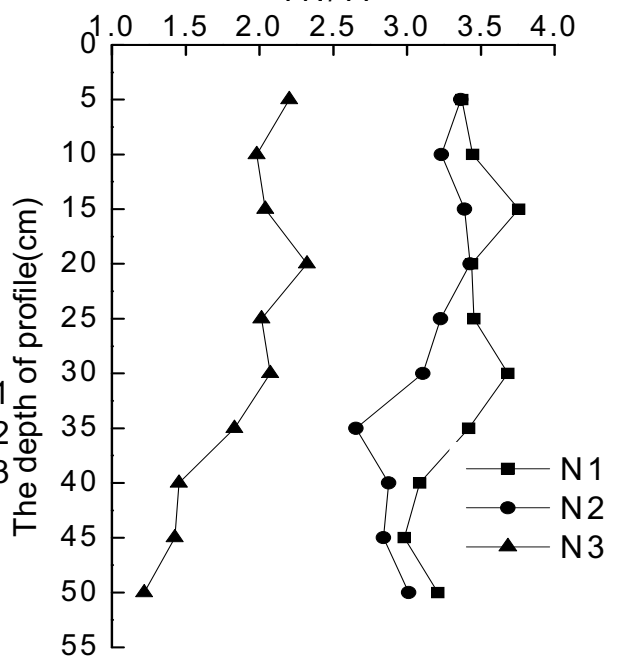

Fig. 13. The vertical distribution of TN/TP of each sampling point

into the lake, increasing the risk of eutrophication in the Longbao Lake. Therefore, the Longbao Lake had a high potential for eutrophication. 
Our results showed that the concentrations of TOC, TP, and TN all reduced gradually with the increase of sediment depth (Figs. 8-11), attributed by the deposition. Lehtoranta et al. (1997) studied the accumulation of nutrients (N and P) in sediments in the Eastern Gulf of Finland, found that they had similar trends and showed that the mean TN and TP was approximately 40 and $50 \%$ higher in the sediment surface than in the deeper layer, respectively. Feng (2006) also reported a decrease of TN in the sediments with increasing depth, in Dianchi Lake in China.

In the three sampling sites, the TOC, TP, and TN, contents of $\mathrm{N} 2$ were higher than those of N1, and the N3 contents were the lowest (Figs. 2-4). The variance should result from the nutrients inputs surrounding the sampling sites. The sampling sites of N2 and N1 are, respectively, located in the west and east sides of the lake, closed to the lakeside with the wetlands. The great primary productivity of wetlands in summer could contribute to more nutrients with $\mathrm{N}, \mathrm{P}$ and organic matter, which were input into the both sites. In addition, with grazing surrounding the lake, the nutrients with livestock manure could be transferred into the sites nearby, due to runoff. In the comparison of $\mathrm{N} 1$ and $\mathrm{N} 2$, the $\mathrm{N} 3$ site is located in the central part of the Lake; therefore, the productivity of wetlands and grazing had lesser effect on the nutrients inputs of the N3 site. Furthermore, the TOC, TP, and TN content in the three sites varied in different seasons (Figs. 2-4). Specifically, the TOC, $\mathrm{TN}, \mathrm{TP}$ contents in October were higher than in May. During summer, from May to October, the wetlands and grasslands had a great productivity with more biomass, which input more nutrients into the water system, especially organic matter. The summer was not only the season for plants growing rapidly, but also for active growing and breeding period for animals and birds. On the one hand, some migratory birds, such as Black Stork (Ciconia nigra), Lark (Alauda positos), etc., would migrate to the Longbao Lake in May and leave in October. The birds lived in the wetland and produced bird manure into the wetland and water body. On the other hand, the grasslands surrounding lakes had a greatest grazing intensity, since the drinking water was available for livestock. The grazed livestock had a great activity on the grassland and wetland. And the increasing number of livestock from May to October would lead to more manure input into the ecosystem. And the greater rainfall in summer would cause more runoff that accelerated nutrients inputs into the lake. What's more, the greater number of tourists might affect the water quality. These reasons were combined to attribute to higher nutrients inputs in Longbao Lake in October. 


\subsection{Correlation of TN and TP, TOC and TN}

In our results, a strong correlation was detected between TN and TP in the wetland sediments of Longbao Lake $\left(R^{2}=0.968\right)$. The correlation between $\mathrm{TN}$ and TP testified that $\mathrm{N}$ and $\mathrm{P}$ in the sediment had the same source ( $\mathrm{Li}$ and Song 2005). Xiang et al. (2014) did research on the $\mathrm{N}$ and $\mathrm{P}$ pollution in the eastern Bay of Tai Lake area, and indicated that TP and TN showed a significant positive correlation in the surface of sediments, so that the $\mathrm{N}$ and $\mathrm{P}$ in sediments result from similar sources. This conclusion is consistent with the study on Chao Lake (Li 2010).

Some studies showed that $\mathrm{C} / \mathrm{N}$ ratio of sediments can effectively indicate the source of organic matter (Chen and Wan 2000). So the sediments in the lake had the two sources of organic matter, including endogenesis and exogenous. With the endogenesis, the catabolite of aquatic organisms contained more protein, and the TOC/TN value was generally less than 7 . With exogenous, terrigenous higher plants were rich in lignin but less protein, with the $\mathrm{TOC} / \mathrm{TN}$ values $20 \sim 30$. In our research, the TOC/TN ratio in the sediment varied from 11.14 to 18.14 in the three sites in Longbao Lake (Fig. 12). It is stated that exogenous inputs of nutrients from grassland had a major effect on the sediment in Longbao Lake. Therefore, exogenous inputs of nutrients or pollution might be the major factor for the high potential for eutrophication in the Longbao Lake. The efficient solutions, for avoiding eutrophication and protecting the wetland in the Longbao Lake, should be reducing grazing intensity, and lowing the pollution and damage caused by human activities.

\section{CONCLUSION}

With the profile depths, the content of TOC, TP, TN with sediments in the Longbao Lake appeared in a decreasing trend. The higher nutrients were input into Longbao Lake in October, compared to May, due to the greater plant growth, and higher intensity on animals, birds and grazing, and so on. The significant correlation between $\mathrm{TN}$ and TP indicated that $\mathrm{N}$ and $\mathrm{P}$ in the sediment had the same source. Although the Longbao Lake had a great water quality, the slightly continuous increases on TOC, TN, and TP with the sediments suggested a high potential for eutrophication. Since the TOC/TN ratio in the sediment varied from 11.14 to 18.14 in the three sites in Longbao Lake, exogenous inputs of nutrients or pollution might be the major factor for the high potential for eutrophication in the Longbao Lake. Therefore, the human activities surrounding the Longbao Lake, especially grazing, should be the great concern for environmental protection in the Longbao Lake. 
Acknowledgements. This research was financially supported by The National Natural Science Funds Fund (No. 31260128), international cooperation project of Qinghai Province Science and Technology Agency (2013-H806 ), and China New Zealand plateau grassland nutrient flow and sustainable production research (2015DFG31870) international cooperation project of the Ministry of science and technology; this study is finished in the laboratory of Eco-environmental Engineering College of Qinghai University, thanks for providing the testing facility and accessories in the laboratory measurements.

\section{References}

Barbier, E.B., M.C. Acreman, and D. Knowler (1997), Economic Valuation of Wetlands: A Guide for Policy Makers and Planners, Ramsar Convention Bureau, Gland, Switzerland.

Catalan, J., M.G. Barbieri, F. Bartumeus, P. Bitusik, I. Botev, A. Brancelj, D. Cogalniceanu, M. Manca, A. Marchetto, N. Ognjanova-Rumenova, S. Pla, M. Rieradevall, S. Sorvari, E. Stefkova, E. Stuchlik, and M. Ventura (2009), Ecological thresholds in European alpine lakes, Freshwater Biol. 54, 12, 2494-2517, DOI: 10.1111/j.1365-2427.2009.02286.x.

Chen, J.A., and G.J. Wan (2000), Study on the environmental record of modern sediments in the Yunnan Cheng Sea, J. Mineral. 20, 2, 112-116.

Chen, Y.F., H. Liu, W.T. Zou, and H.Q. Zhang (2012), Quantitative study on the drive factors of wetland change in three river's source area, Forest Sci. 25, 5, 545550.

Ding, S.M., C. Han, Y.P. Wang, L. Yao, Y. Wang, D. Xu, Q. Sun, N.W. Paul, and C.S. Zhang (2015), In situ, high-resolution imaging of labile phosphorus in sediments of a large eutrophic lake, Sci. Direct. 74, 100-109, DOI: 10.1016/ j.watres.2015.02.008.

Feng, F. (2006), Study on the Vertical Distribution of Sedimentary Microbial Biomass, Species of Carbon, Nitrogen, Phosphorus and their Correlation, The Chinese Academy of Sciences Institute of Hydrobiology, Wuhan.

Guo, Z.Y. (2007), Distribution and Transformation of Phosphorus Fractionations in the Sediments of Three Typical Urban Shallow Lakes-Xuanwu Lake, Damning Lake and Mochou Lake, Hehai University, Nanjing.

ISSCAS (1987), Physical and Chemical Analysis of Soil, Science and Technology Press, Shanghai, Institute of Soil Science, Chinese Academy of Sciences, Nanjing, China, 189-194.

Lehtoranta, J., H. Pitkanen, and O. Sandman (1997), Sediment accumulation of nutrients(N, P) in the Eastern Gulf of Finland (Baltic Sea), Water Air Soil Poll. 99, 477-486. 
Li, L. (2010), Studies on the Distribution of Organic Carbon, Nitrogen, Phosphorous and Their Correlation in ChaoHu Wetland Sediments, Anhui Normal University, Hefei.

Li, R.X., M.Y. Zhu, S. Chen, R.H. Lu, and B.H. Li (2001), Responses of phytoplankton on phosphate enrichment in mesocosms, Acta Ecol. Sin. 21, 4, 603-607.

Li, X.G., and J.M. Song (2005), Source and biogeochemical characteristics of nitrogen and phosphorus in Jiaozhou Bay sediments, Oceanol. Limnol. Sin. 36, 6, 562571.

Lin, J.C. (2003), Biological diversity conservation in Yushulong National nature reserve of Qinghai province, Jilin Agr. Sci. Technol. 32, 4, 37-40.

Lin, Q. (2008), Longbao Lake: home of black-necked crane, Hum. Nature 4, 7, 56-57.

Lu, S., H. Shi, P. Li, and Y.L. Yang (2009), Assessment on the currently environmental impact of surface water in Yangtze River of the source of three rivers, Environ. Health 26, 7, 604-605.

Ma, Z.T., F.X. Li, P. Li, and J.S. Xiao (2009), The study of dynamic change of ecological environment of Longbao area in Qinghai Yushu, Pratacultur. Sci. 26, 7, 6-11.

Mitch, W.J., and J.G. Gosselink (2000), Wetland, 3rd ed., John Wiley \& Sons, New York.

Qing, D.H. (2013), The Source Region of Ecological Protection and Sustainable Development in Sanjiang, Science Publishing House, Beijing, 29-30.

Shi, H.X., S.J. Lu, P. Li, and Y.L. Yang (2009), Assessment on the currently environmental impact of surface water in Yellow River of the source of three rivers, Anhui Agr. Sci. 17, 1134-1136.

Søndergaard, M., E. Jeppesen, T.L. Lauridsen, C. Skov, N.E.H. Van, R. Roijackers, E. Lammens, and R. Portielje (2007), Lake restoration:successes, failures and long-term effects, J Appl. Ecol. 44, 6, 1095-1105, DOI: 10.1111/ j.13652664.2007.01363.x.

Sun, Z.G., and J.S. Liu (2006), The actuality, problems and sustainable utilization countermeasures of wetland resources in China, J. Arid Land Resour. Environ. 20, 2, 83-88.

Xiang, S.L., M.Y. Zhu, G.W. Zhu, and H. Xu (2014), Pollution charateristics of nitrogen and phosphorus in the sediment of the growth area of the aquatic plants in the east of Taihu Lake, Acta Sediment. Sin. 32, 6, 1083-1088.

Yang, S.Z., H.J. Jin, Y.J. Ji, Z. Wei, and R.X. He (2008), Revegetation in Permafrost Regions along a Linear Project, J. Glaciol. Geocryol. 30, 5, 875-822.

Zheng, J. (2011), Study of Nature Protection Area of Qinghai, Qinghai People's Publishing House, Xining. 